\title{
An Unusual Form of Motor Neuron Disease Following a Cat Bite
}

\author{
Arthur J. Hudson, Harry V. Vinters, R. Charles Povey, Leslie A. Hatch, \\ Dean H. Percy, John H. Noseworthy and John C.E. Kaufmann
}

\begin{abstract}
A case of motor neuron disease with clinical and pathological resemblance to amyotrophic lateral sclerosis (ALS) in a woman who was severely bitten on the ankle by a cat is described. Weakness first appeared at the ankles and relentlessly advanced proximally, terminating in death from pulmonary failure in a year. A number of unusual features that are uncharacteristic of ALS were found that included a markedly elevated antinuclear antibody titre in the serum and the presence of prominent oligoclonal bands in the cerebrospinal fluid. The spinal cord showed loss of anterior horn cells and pyramidal degeneration that are characteristic of ALS, but an extraordinary finding was the presence of transmural granulomatous inflammation of numerous small and medium sized vessels, especially veins, in the subarachnoid space around the cord. There were also inflammatory changes in the brainstem and spinal cord consisting of microglial and astrocytic nodules and perivenous cuffing by mononuclear cells. Ill-defined hyaline eosinophilic cytoplasmic inclusions were seen in some remaining anterior horn cells. No viral particles were found by electron microscopy despite an extensive search. Virological studies were inconclusive but there is reason to believe that this patient's illness was caused by an as yet unidentified virus.
\end{abstract}

RÉSUMÉ: Un type rare de maladie du neurone moteur à la suite d'une morsure par un chat Description d'un cas de maladie du neurone moteur présentant des similitudes cliniques et pathologiques avec la sclérose latérale amyotrophique, chez une femme ayant été sévèrement mordue à la cheville par un chat. Elle présenta d'abord de la faiblesse aux chevilles, avec progression au niveau proximal sans rémission, évoluant vers la mort par défaillance pulmonaire en l'espace d'un an. La patiente présentait en outre certaines particularités inhabituelles dans la sclérose latérale amyotrophique, dont: une élévation marquée du titre d'anticorps antinucléaires dans le sérum et la présence de bandes oligoclonales importantes dans le liquide céphalorachidien. La moelle épinière présentait une perte de cellules de la corne antérieure et une dégénérescence du faisceau pyramidal qui sont caractéristiques de la SLA. Cependant, la présence d'inflammation granulomateuse transmurale au niveau du nombreux vaisseaux, surtout des veines, de petit et de moyen calibre, dans l'espace sous-arachnö̈dien autour de la moelle, constitue une trouvaille étonnante. Le tronc cérébral et la moelle épinière présentaient également des changements inflammatoires constitués surtout de nodules de cellules microgliales et d'astrocytes, et des manchons périveineux de cellules mononucleaires. Des inclusions cytoplasmiques de matière eosinophile hyaline étaient présentes dans certaines cellules restantes de la corne antérieure. La microscopie électronique n'a révélé aucune particule virale en dépit d'une recherche extensive. Malgré des études virologiques non concluantes, il y a lieu de croire que la maladie de cette patiente a été causée par un virus encore non identifié.

Can. J. Neurol. Sci. 1986; 13:111-116

The etiology of the most common of the motor neuron diseases, amyotrophic lateral sclerosis (ALS), is unknown. The possibility of a slow virus infection has been explored by a number of techniques including the intracerebral inoculation of brain tissue from ALS patients into non-human primates. The disease has not been transferable $e^{1.2}$ nor has there been confirmed identification of an infective agent in the tissues of ALS patients. ${ }^{3.45 .6}$ Yet, a conviction that ALS may be caused by a conventional or unconventional virus persists and is due, largely, to the clinical similarity of the relentlessly and slowly progressive course of ALS to the deterioration that occurs in such infectious diseases as Creutzfeldt-Jakob disease and subacute sclerosing panencephalitis. Moreover, there is resemblance in the anterior horn cell loss to that seen with poliomyelitis although the search for poliovirus has yielded no evidence of virus, even with nucleic acid hybridization studies. ${ }^{7}$ The following report describes a case of motor neuron disease with clinical and pathological similarity to ALS in which weakness and wasting began in the lower extremities within 6 months of a severe cat bite to an ankle. Relentless cephalad progression ended in death from pulmonary failure in a year. At autopsy there were typical findings of ALS and, in addition, inflammatory changes suggestive of a low-grade nervous system infection.

From the Departments of Clinical Neurological Sciences (Dr. Hudson and Dr. Noseworthy), Pathology (Neuropathology) (Dr. Vinters and Dr. Kaufmann) and Microbiology and Immunology. University of Western Ontario (Dr. Hatch): Departments of Clinical Studies (Dr. Povey) and Pathology (Dr. Percy), Ontario Veterinary College, University of Guelph; and the University and St. Joseph's Hospitals, London, Ontario

Received June 17, 1985. Accepted in final form December 17, 1985

Reprint requests to: Dr. A.J. Hudson, Dept. of Clinical Neurological Sciences, University Hospital. London, Ontario, Canada N6A 5A5 


\section{Case Report}

This 54-year old right handed housewife was in good health until July of 1982 when she received a severe cat bite on the dorsum of her right foot. Cellulitis developed which required drainage, debridement and subsequently a skin graft. Culture of the purulent discharge grew Pasteurella multocida and a mixture of anaerobic Gram positive cocci and Gram negative bacilli. From October through December the patient required physiotherapy and progressively improved from walking with a walker to walking with no aids by December, 1982. In January, 1983, almost six months following the cat bite, she became aware of a left foot drop and mild weakness of the left leg. Over the next two months there was relentless progression of this weakness such that by March 1983 she could no longer walk without a cane. By this time she had also developed a right foot drop. In June 1983 she complained of marked weakness of the left leg and moderate weakness of the right leg. There was no associated sensory loss or pain. Past medical history and family history were unremarkable.

Examination of the patient in July, 1983, 6 months after onset of weakness revealed gross weakness of the dorsiflexors and evertors and moderate weakness of the invertors and plantar flexors of the left ankle. There was moderate weakness of the left knee and hip flexors and extensors while on the right side there was slight to moderate weakness of all movement at the ankle and minimal weakness of all knee and hip muscles. Wasting was evident in the anterior tibial group and gastrocnemius on the left. Strength in the upper limbs and trunk was normal except for slight generalized weakness of the left arm, especially shoulder abduction and flexion. There were occasional fasciculations seen over the shoulder muscles and calves bilaterally. The deep tendon reflexes at the ankles were diminished but were normal elsewhere and the right plantar response was extensor. Sensation to all modalities was normal.

A month before her death in early February 1984 the lower extremities were completely paralysed except for a trace of movement at both hips in flexion and extension. There was marked generalised weakness of both upper extremities that was slightly greater proximally than distally. Muscular bulk and tone were generally reduced and the deep tendon reflexes were diminished in the arms, markedly reduced at the knees and absent at the ankles. Sensation remained normal throughout except for some diminution of vibration sense at the ankles. There was minimal facial weakness but speech and swallowing were normal and the remainder of the cranial nerves were intact. The vital capacity a month before death was only 45 percent of the predicted value. Death occurred about 12 months from clinical onset and was attributed to pulmonary failure from respiratory muscular paralysis.

Routine hematological and biochemical studies that were performed 6 months after onset of muscle weakness were negative apart from the serum creatine phosphokinase of $337 \mathrm{u} / \mathrm{L}$ (normal 26 to $140 \mathrm{u} / \mathrm{L}$ ). An antinuclear antibody (ANA) titre was 1:640 on July 8, 1983 and $1: 2560$ on December 9,1983 with a speckled ANA pattern on both occasions.
Antibodies to the non-histone antigens (anti-Sm, anti-RNP, anti-La(SS-B) anti-Ro(SS-A)) and anti-nDNA were negative. The cold agglutinin screen, cryoglobulins, rheumatoid factor and complement (total, C3 and C4) were negative. The serum IgG was slightly elevated on December 9,1983 at $13.10 \mathrm{~g} / \mathrm{L}$ (normal $5.09-12.40 \mathrm{~g} / \mathrm{L}$ ) but within the normal range on July 8 and December 16, 1983. The $\operatorname{lgA}$, IgM and $\lg E$ were normal on all three occasions. There was a marginal elevation of the serum globulins and a slight decrease in the $A / G$ ratio on protein electrophoresis. Lead and mercury determinations in urine were within the normal range. There was no increase in cells in the cerebrospinal fluid (CSF) but the protein was slightly elevated at $470 \mathrm{mg} / \mathrm{L}$ (normal $<450 \mathrm{mg} / \mathrm{L}$ ). The CSF IgG level was slightly elevated $(79 \mathrm{mg} / \mathrm{L}$, normal $<65 \mathrm{mg} / \mathrm{L}$ ) and the $\mathrm{IgG} /$ albumin index was marginally increased at 0.27 (normal $<0.25$ ). A number of oligoclonal bands were present in the cerebrospinal fluid but no oligoclonal bands were seen in the patient's serum (Figure 1). A whole body gallium scan showed no abnormal accumulation. Electromyography showed extensive denervation potentials (positive sharp waves and fibrillation potentials), in both upper and lower limbs with normal sensory potentials. Nerve conduction velocities were normal in July, 1983.

\section{Virological STUdies}

The serum and cerebrospinal fluid of the patient and the serum of the cat, collected 6 months before the patient died, were tested for antibodies to several human and animal pathogens. Table 1 shows those antibodies that were detected. The most significant elevation was the Toxoplasma gondii passive haemagglutination titre of 1:256 in the patient's and cat's serum indicating that both had active toxoplasmosis. There was no detectable antibody in the patient's cerebrospinal fluid making nervous system involvement unlikely (also see Pathology). The markedly elevated serum haemagglutination inhibition titre against rubella $(1: 4096)$ in the patient may also reflect a coincidental infection since no antibody titre was detected in the cerebrospinal fluid. Antibodies to both measles and canine distemper virus were present in the patient's serum (see Discussion). The mildly elevated rabies titre of $1: 32$ in the cat serum is consistent with a recent vaccination. Other elevated antibody titres are of doubtful significance in relation to the patient's illness.

The patient's serum was negative against all the cat viruses tested and also against mycoplasma pneumoniae, Rickettsia burneti, Rocky Mountain Spotted Fever, Influenza A and B, Cytomegalovirus, Respiratory syncytial virus, Psittacosis, Ade-

Table 1. Serological findings in patient and cat to selected bacterial and viral antigens

\begin{tabular}{|c|c|c|c|c|}
\hline \multirow[b]{2}{*}{ Organism } & \multirow[b]{2}{*}{ Test* } & \multicolumn{2}{|c|}{ Patient } & \multirow{2}{*}{$\begin{array}{c}\text { Cat } \\
\text { Serum }\end{array}$} \\
\hline & & Serum & CSF & \\
\hline Canine distemper & VN & 30 & $<2$ & $<2$ \\
\hline Feline calcivirus & VN & $<2$ & $<2$ & 6 \\
\hline Feline parvovirus & $\mathrm{HI}$ & $<8$ & $<8$ & 12 \\
\hline Herpes simplex & $\mathrm{CF}$ & 10 . & $<8$ & - \\
\hline Measles & $\mathrm{CF}$ & 40 & $<8$ & - \\
\hline Mumps & $\mathrm{CF}$ & $<10$ & 2 & - \\
\hline \multicolumn{5}{|l|}{ Poliovirus } \\
\hline Type I & $\mathrm{VN}$ & 16 & - & - \\
\hline II & VN & $<4$ & - & - \\
\hline III & $\mathrm{VN}$ & $<4$ & - & - \\
\hline Psittacosis & CF & $<10$ & - & 10 \\
\hline Rabies & RFFIT & $<8$ & - & 32 \\
\hline Rubella & $\mathrm{HI}$ & 4096 & $<8$ & - \\
\hline Streptozyme** & PH & 50 & - & 100 \\
\hline Toxoplasma gondii & PH & 256 & $<8$ & 256 \\
\hline
\end{tabular}

*Reciprocal titres in serum and cerebrospinal fluid (CSF) are shown. CF - complement fixation, $\mathrm{HI}$ - haemagglutination inhibition, $\mathrm{PH}-$ passive haemaglutination, RFFIT - rapid fluorescence focus inhibition test, VN — virus neutralization.

**In the streptozyme test 50 is considered negative and 100 or more positive. 
novirus and Varicella-zoster by complement fixation and negative against Brucella abortus and Francisella tularensis by agglutination. The Paul Bunnell test was negative. The cerebrospinal fluid was negative against Cytomegalovirus and Varicellazoster. The cat serum was negative by complement fixation against Rickettsia burneti and Rocky Mountain Spotted Fever, by agglutination against Francisella tularensis and by neutralisation against feline herpesvirus 1 , feline infectious peritonitis (corona virus) and feline leukemia virus. Examination of the cat serum for P-27 feline leukemia virus antigen was also negative.

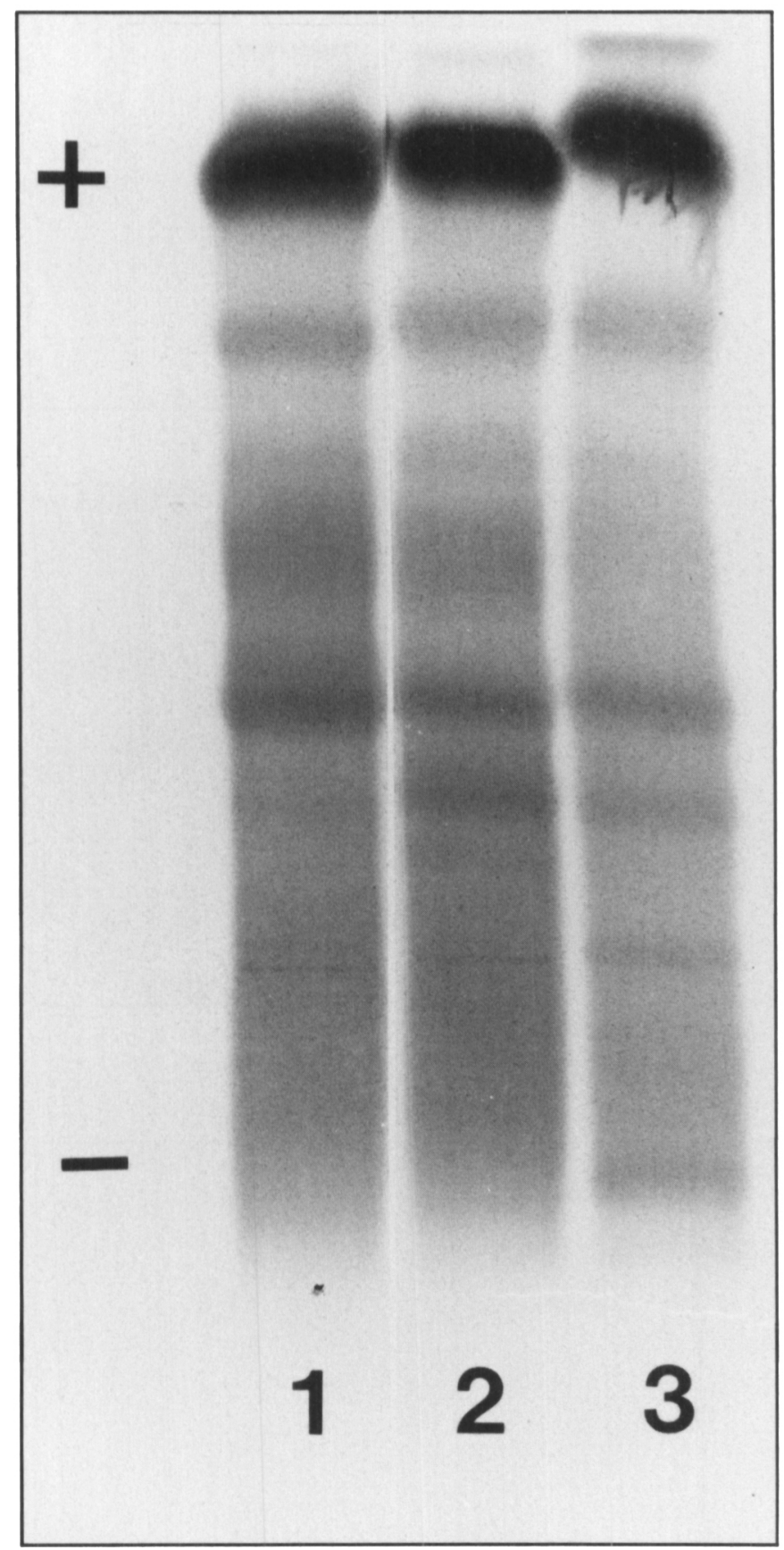

Figure I. - Agrose electrophoresis (Panagel) of normal cerebrospinal fluid $(C S F)$ is shown in lane l, patient's serum in lane 2 and patient's CSF in lane 3. Prominent oligoclonal banding is seen in the patient's CSF at the site indicated by the cathode marker. Oligoclonal bands were not seen in the patient's serum. The pattern of CSF oligoclonal banding remained unchanged through the course of her illness.
Cerebral and cerebellar tissues, obtained post mortem from the patient were tested for virus and Toxoplasma gondii and were negative. Sections of the spinal cord were tested for rabies antigen using both the peroxidase-antiperoxidase test and indirect immunofluorescent test modified for paraffin sections. Both tests were negative for rabies antigen. Direct Giemsa smears of the brain tissue showed no Toxoplasma and no inclusions. Day old suckling mice were inoculated by the subcutaneous and intracerebral routes and showed no signs of disease after 14 days. Giemsa smears of their brains after autopsy were negative for Toxoplasma gondii. Each tissue was also inoculated into Hep-2, Rhesus monkey kidney, African green monkey kidney, human amnion, human prepuce and Crandall Cat kidney tissue culture monolayers with negative results. A second blind passage was performed again with negative results. Each specimen was under test for at least 28 days in each tissue.

\section{Pathological Studies}

A complete autopsy was performed on the patient and the cat. Both light and electron microscopy were done on the central and peripheral nervous system of the patient whereas light microscopy only was done on other organs of the patient

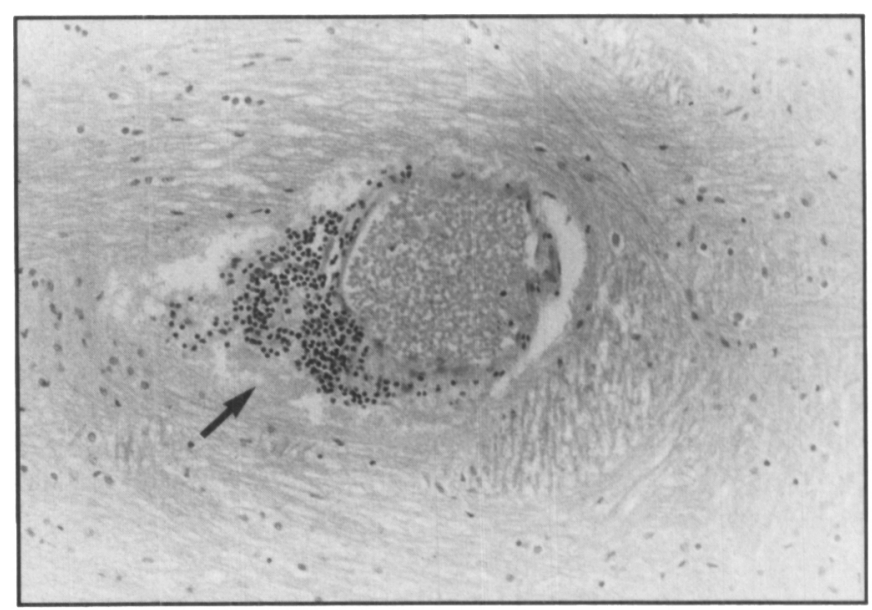

Figure 2 - Section of medulla show's markedperivascular cuffing by mononuclear inflammatory cells (arrow). Hematoxylin and eosin, $x 205$.

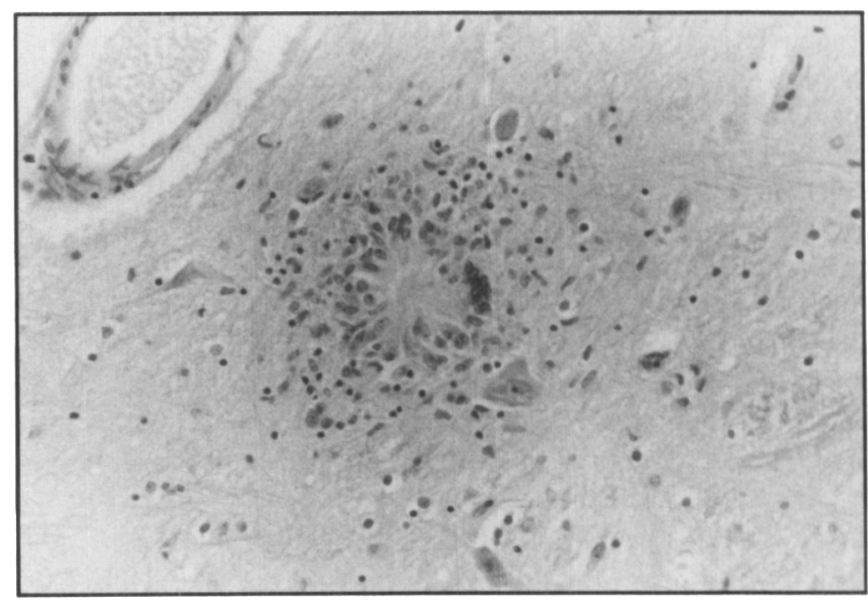

Figure 3 - Inflammatory nodule at pontomedullary junction show's a cluster of astocytes, microglia and a fibrillary core. Hematoxylin and eosin, $x$ 320. 
and on the cat. No abnormality was found in the cat except a low grade membranoproliferative glomerulopathy. The significant pathological findings in the patient were found in the central and peripheral nervous system and skeletal muscle.

The fresh brain weighed $1430 \mathrm{~g}$ and was fixed in $20 \%$ formalin, as was the spinal cord. The only abnormality noted at the time of brain cutting was slight atrophy of the anterior superior cerebellar vermis, for which there was no microscopic correlation. The spinal cord including ventral roots was unremarkable. Histologic sections showed no significant neuron loss, gliosis or spongy change in any area of cortex. The prefrontal gyri were well preserved, the only change being mild etat criblé in the white matter. The amygdala and the hippocampus were normal except for some feruginized capillaries adjacent to the dentate fascia. Histological sections from all areas of the brainstem showed scattered inflammatory (microglial and astrocytic) nodules and perivenous cuffing by mononuclear inflammatory cells (Figures 2 and 3). These changes were most pronounced in the lower pons and medulla. There was no limbic component to the inflammation. Neuron loss in brainstem nuclei (e.g. the hypoglossal) was minimal, although slight cell loss and gliosis were observed in the facial nuclei and inferior olivary nuclei, bilaterally. Other findings in the brainstem included: slight pallor and vacuolization of the corticospinal tracts, and gliosis of the pyramids, an occasional globose neurofibrillary tangle in the locus ceruleus, many neuroaxonal spheroids in the gracile nuclei and a hyaline intracytoplasmic inclusion in a neuron of the facial nucleus. Neuroaxonal spheroids were not identified in any other portion of the nervous system.

Sections of spinal cord, comprised multiple levels of the cervical, thoracic, lumbar and also sacral cord. The anterior roots when present in the blocks were atrophic with few myelinated fibres whereas the posterior roots were normal (Figure 4 , $a$ and $b$ ). Sections of the spinal cord showed slight degeneration of the lateral and anterior corticospinal tracts (Figure S) and diffuse severe neuron loss and associated gliosis in the anterior grey horns, increasing caudally (Figure 6, a and b). There was relative preservation of Clarke's column neurons in the thoracic cord and cells of Onufrowicz nucleus in the sacral cord. The posterior columns appeared normal. Parenchymal inflammatory nodules similar to those in the brainstem were only occasionally observed and a few vessels showed perivascular lymphocyte cuffs. Cuffs were present in the leptomeninges, especially posteriorly. Of remaining anterior horn cells, a few showed ill-defined hyaline eosinophilic cytoplasmic inclusions but central chromatolysis was not seen. A few of the cytoplasmic inclusions showed similarities to Bunina bodies. There was transmural granulomatous inflammation of several small and medium-sized vessels (especially veins) in the subarachnoid space around the cord (Figure 7). Appropriate stains for microorganisms (PAS, Grocott methenamine silver, acid-fast, Gram and Wade-Fite) in these regions were negative. No parenchymal infarcts were identified near these vascular lesions. There was no evidence of central nervous system toxoplasmosis. An extensive search for viral particles by electron microscopy throughout all levels of spinal cord failed to show such organisms although anterior horn cells were clearly identified.

Sections of skeletal muscle showed a variable degree of neurogenic atrophy, ranging from slight (deltoid) to severe (rectus abdominis). An occasional vessel in the skeletal muscle and the peroneal nerves showed inflammatory changes similar to those described for meningeal vessels around the spinal cord (see above). Occasional focal collections of mononuclear cells also were found in the stroma of the biliary tracts of the liver and around a bronchus but none were seen in other organs. Dorsal root ganglia were not available for examination.
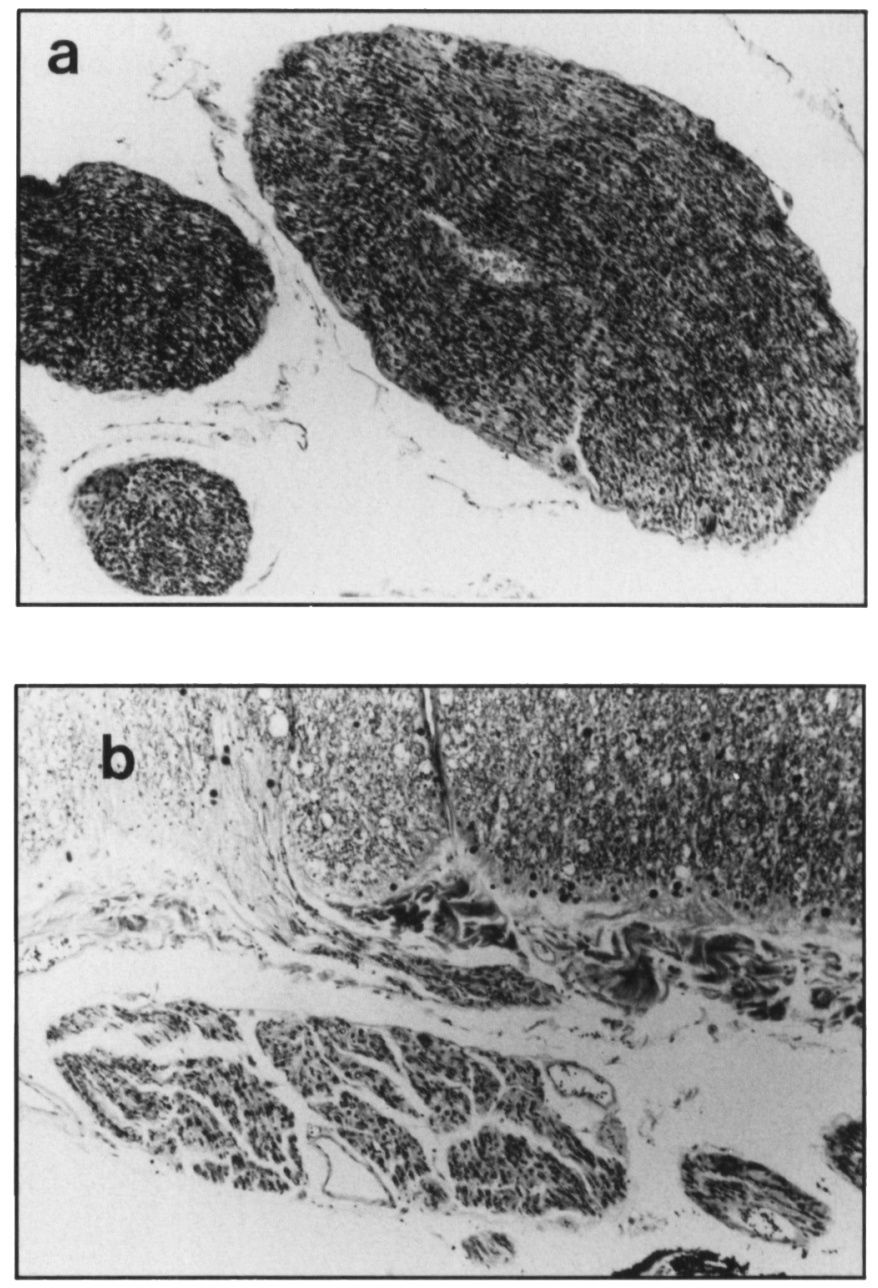

Figure 4-(a) Posterior nerve roots are of normal size while anterior nerve roots (b) are atrophic. Solochrome R/Cresyl violet, both $\times$ /26.

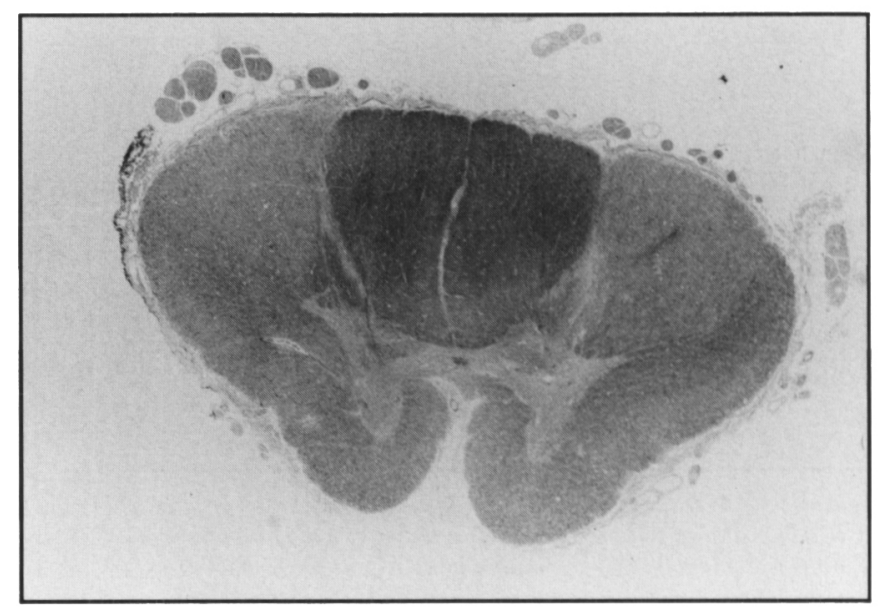

Figure 5 - Section of thoracic spinal cord show's symmetrical pallor of the corticospinal tracts. Solochrome $R, \times 14$. 

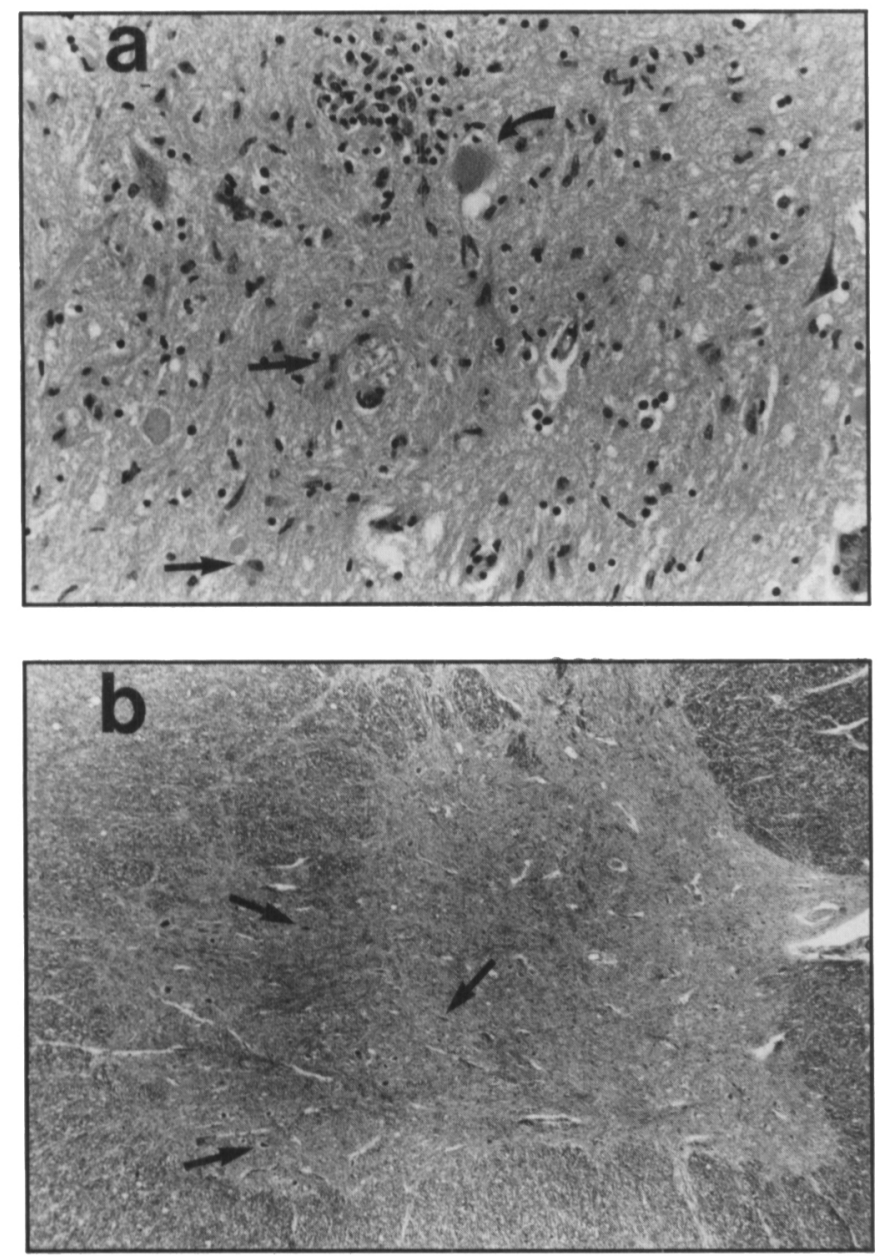

Figure 6- (a) Anterior horn of grey matter of lumbar cord. A ghost neuron (curved arrow) lies adjacent to an inflammatory focus of microglia and round cells, possibly a focus of neuronophagia. Neurons are scanty and there is obvious gliosis. Astrocytic nuclei (straight arrows) are numerous. Haematoxylin and eosin X 315. (b) Anterior horn of grey matter of cervical cord showing reduced numbers of motor neurons (arrows) Solochrome R/Cresyl violet, $x 40$.

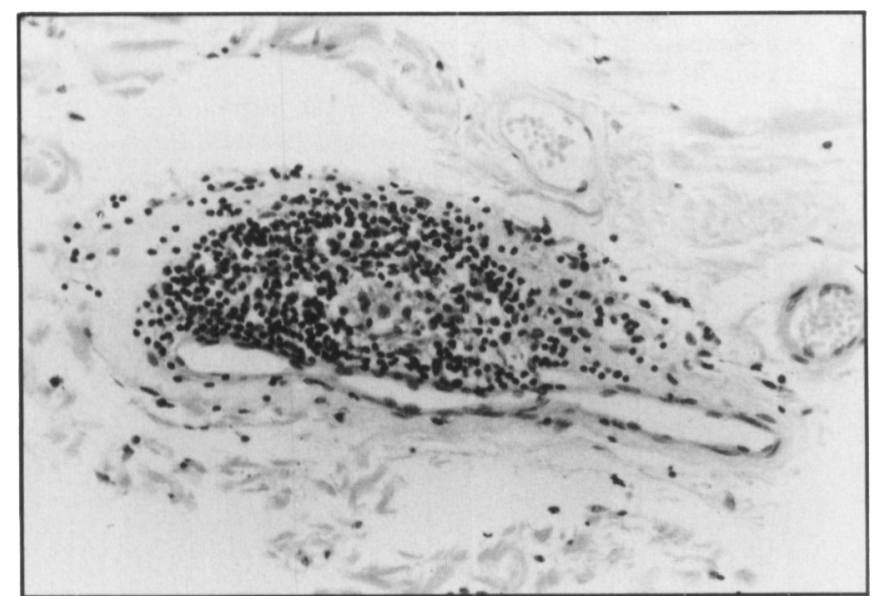

Figure 7-A meningeal vessel in subarachnoid space adjacent to dorsal aspect of thoracic spinal cord shows focal transmural granulomatous inflammation. Hematoxylin and eosin, $x 305$

\section{Discussion}

Although the motor neuron disease in this patient had clinical findings that were compatible with the diagnosis of ALS there were a number of unusual features. Characteristically, clinical onset in classical ALS consists of focal weakness of either the bulbar or limb muscles, especially in the upper limbs, with focal weakness subsequently developing at other sites. In the present case onset occurred with weakness and wasting in the legs that was followed by a relentless cephalad progression and no other focal findings. In addition, the progession of the illness was unusually rapid with a duration of one year as compared to the usual life expectancy in ALS of two to four years. The most unusual features were the presence of oligoclonal bands in the CSF and the perivascular round cell infiltration and inflammatory nodule formation in the brainstem and spinal cord that are more consistent with a low grade encephalomyelitis than ALS. In our experience prominent cerebrospinal fluid oligoclonal bands are not seen in motor neuron disease ${ }^{8}$ and in this case suggest the production of immunoglobulin of restricted but unidentified heterogeneity within the central nervous system as is seen in inflammatory or immunologically mediated neurological illness. Apart from these differences, the clinical and pathological features were consistent with ALS. 9

There are a number of reasons for assuming a relationship of the cat bite to the motor neuron disease, especially in terms of an infective etiology. The most apparent are onset of the disease in the lower limbs where the bite occurred and the short interval ( 6 months) from the time of the cat bite to the first clinical signs. While the clinical evidence suggests a relationship of the bite to the motor neuron disease it is the pathological evidence of inflammatory changes in the nervous system that provides the strongest support for an infective process. Although the inflammatory changes were much more striking in the brainstem than the spinal cord, where the effects of the disease were greatest, it appears that the disease process was advancing rostrally and had died out in the spinal cord. An incubation period of up to 6 months is quite consistent with conventional or unconventional virus infection of the nervous system. Viral antibody tests to a number of human and animal pathogens were negative, however, and the viral antibody titres that were elevated, such as the canine distemper virus, measles and rubella titres, are of doubtful significance. The rubella titre although markedly increased, was negative in the cerebrospinal fluid and is frequently elevated in asymptomatic individuals. The elevated titre to canine distemper virus probably reflects an immune response to measles since the canine distemper virus is believed to be non-pathogenic to man and antibodies to measles virus cross-react with canine distemper virus. Measles in man (and canine distemper virus in dogs) is associated with a slow persistent infection that can develop in different organ systems several months or years after the initial infection ${ }^{10,11,12}$ but the titre in this case was lower than is usually found in persistent measles infection. Although both the patient and cat probably had active toxoplasmosis there was no clinical or pathological evidence of central nervous system toxoplasmosis. Cat scratch fever was considered but the patient did not have lymphadenopathy or clinical evidence of encephalopathy.

A constellation of neuronal cytoplasmic inclusions may be seen in residual brainstem and spinal cord motor neurons of ALS patients. ${ }^{13}$ Some of these, such as Bunina bodies, seem 
characteristic of, but not specific for, ALS whereas others such as the hyaline "colloid" inclusion found in this case were probably a function of normal aging ${ }^{13}$ and of unknown clinical importance. The presence of such inclusions does not in itself indicate a viral aetiology for the disease, although morphologically similar inclusions are an important finding in rabies encephalitis. ${ }^{14}$ The parenchymal inflammatory lesions described in the lower brainstem of this patient were more pronounced than in previously reported examples of neuronophagia occurring in ALS. ${ }^{15}$ We cannot suggest a specific etiology for the granulomatous angiitis of spinal cord leptomeningeal vessels noted in this patient. There is increasing evidence that classical granulomatous angiitis of the central nervous system may be associated with herpes zoster infection ${ }^{16}$ but the serum and cerebrospinal fluid varicella-zoster titre in the present case was negative. Motor neuron disease has been linked to neoplastic disease, especially plasma cell dyscrasia ${ }^{17}$ but no evidence of this was found.

The failure to disclose an infective agent despite morphological evidence in support of an infective etiology in this case, or ALS generally, should not deter a persistent search for virus. Onset of clinical signs in the lower limbs in relation to the cat bite is reminiscent of the well-recognized association of initial neurological involvement of anatomical structures adjacent to the site of viral entry in other central nervous sytem diseases of known viral etiology (e.g. rabies). The possibility of an autoimmune process producing the nervous system changes also must be considered especially in view of the marked elevation of the antinuclear antibody titres. No evidence of lupus, Sjogren's or rheumatoid disease was found.

In summary, we believe that the findings in this case, especially the prominent oligoclonal CSF bands, granulomatous angiitis and parenchymal inflammatory nodules within the central nervous system, suggest that this case of motor neuron disease was caused by an infectious agent. Since these findings are unusual the implication is that ALS is not a single entity but may be a syndrome with a number of causes, at least one of which may be infective.

\section{ACKNOWLEDGEMENTS}

The authors are grateful to Dr. Murray Gardner of the Department of Medical Pathology, University of California, Davis, Davis California for his assistance in performing the FeLV-P-27 antigen detection and FeLV neutralization tests. They are also appreciative of the assistance of Dr. Sze Chang of St. Mary's Hospital, Kitchener, Ontario for performing the autopsy and preparing the tissues on the patient for detailed study. We wish to thank Dr. K.M. Charlton the Head of the Pathology Section and Rabies Unit, Agriculture, Canada for tests of rabies antigen.

\section{REFERENCES}

1. Johnson RT. Virological studies of amyotrophic lateral sclerosis: an overview. In: Andrews JM, Johnson RT, Brazier MAB, eds. Amyotrophic Lateral Sclerosis. Recent Research Trends. UCLA Forum in Medical Sciences No.10. New York: Academic, 1976: 173-180.

2. Gibbs CJ, Gajdusek DC. ALS, Parkinson's disease and ALS Parkinsonian-dementia complex on Guam: a review and summary of attempts to demonstrate infectious etiology. J Clin Path 1972; 6: 132-140.

3. Cremer N, Oshiro L, Norris F. Cultures of tissues from patients with amyotrophic lateral sclerosis. Arch Neurol 1973; 29: 331-333.

4. Weiner LP, Stohlman SA, Davis RL. Attempts to demonstrate virus in amyotrophic lateral sclerosis. Neurology $1980 ; 30$ : 1319-1322.

5. Cremer NE, Oshiro LS, O'Keefe B, Norris FH, Jr. No viruses in muscles of patients with amyotrophic lateral sclerosis. New Eng J Med 1981; 304: 489.

6. Salazar AM, Masters CL, Gajdusek C, Gibbs CJ. Syndromes of amyotrophic lateral sclerosis and dementia: relation to transmissible Creutzfeldt-Jakob disease. Ann Neurol 1983; 14: 17-26.

7. Kohne DE, Gibbs CJ, White L, Tracy SM, Meinke W, Smith RA. Virus detection by nucleic acid hybridization: examination of normal and ALS tissues for the presence of poliovirus. J gen Virol 1981; 56: 223-233.

8. Ebers GC, Paty DW. CSF electrophoresis in one thousand patients. Can J Neurol Sci 1980; 7: 275-280.

9. Hudson AJ. Amyotrophic lateral sclerosis and its association with dementia, parkinsonism and other neurological disorders: A review. Brain 1981; 104: 217-247.

10. Meulen V ter, Martin SJ. Genesis and maintenance of a persistent infection by canine distemper virus. J gen Virol 1979; 32: 431-440.

11. Lincoln SD, Gorham JR, Ott RL, Hegreberg GA. Etiologic studies on old dog encephalitis. Veterinary Pathology 1971; 8: 1-8.

12. Fuccillo D, Kurent JE, Sever JL. Slow virus diseases. Annual Rev Microbiol 1974; 28: 231-264.

13. Iwata M, Hirano A. Current problems in the pathology of amyotrophic lateral sclerosis. In: Zimmerman HM ed. Progress in Neuropathology. New York: Raven Press, vol 4, 1979; 277-298.

14. Dupont JR, Earle MK. Human rabies encephalitis. A study of 49 fatal cases with a review of the literature. Neurology 1965; 15: 1023-1034.

15. Brownell B, Oppenheimer DR, Hughes JT. The central nervous system in motor neurone disease. J Neurol Neurosurg Psychiat 1970; 33: 338-357.

16. Johnson ES. Granulomatous angiitis of the nervous system and prior herpes zoster infection. Abstract A9, Can.Assoc. Neuropath. Annual Meeting (Ottawa), 1984.

17. Latou N. Plasma cell dyscrasia and motor neuron disease. In: Rowland LP ed. Human Motor Neuron diseases. Advances in Neurology. New York: Raven Press, vol 36, 1982: 273-279. 